\title{
Zine as a Media of Subculture and Literacy in Semarang
}

\author{
Khothibul Umam* and Gregorius Tri Hendrawan Manurung \\ Department of Indonesian Literature, Faculty of Humanities, Diponegoro University, Semarang - \\ Indonesia
}

\begin{abstract}
This research was conducted to investigate the development of zine and its impacts on the subculture and literacy in Semarang. The method used in this research was the Sociology of Literature approach, focusing on the zine production and distribution in Semarang from 2000 to 2010. The data was taken from the interviews with zinesters alongside their products. The data collection methods used were observations and deep interviews. The observation method is used to cover the data related to zine production while the deep interview is used to cover the data related to the history of zine development and its impacts on the readers. The analytical method used in this research is investigating how far zine production in Semarang is able to give impacts of literacy to both the creators and readers.
\end{abstract}

Keywords: zine, literacy, subculture, Semarang.

\section{Introduction}

Similar to other cities, Semarang as one of the big cities in Indonesia cannot be separated from cultural dynamics. Various cultures live here, from traditional and mass culture to sidestream culture. This sidestream culture becomes a kind of subculture or counterculture that is commonly embraced by the youth.

One of the subcultures is the emerging of zine or fanzine. Describing zine is quite challenging. According to the Oxford English Dictionary, zine is a shortened form of fanzine. This kind of media first appeared in the United States around the 1930s from a group of science fiction lovers in the United States of America. Its role was also significant in various kinds of underground publications, focusing on social and political issues around the 1960s. It grew bigger when the hardcore/puck scene began to use it as a communication media among their communities.

A zine is generally created by using both text and visual which then photocopied. Profit is not the main purpose of a zine publication. Various kinds of zines set their focuses on particular themes, such as arts and photography, literature, social and politics, music, perzines (personal zines), travel, health, foods, etc. These diverse themes are definitely made with DIY (Do it Yourself) spirit, and they fight against the mainstream culture [1]. In Semarang,

* Corresponding author: khothibulumam@lecturer.undip.ac.id 
alternative publications began to appear in the late 1990s. Mostly they were created by the scenesters, mainly punk and underground. In their variations, there were also zines created by the people from literature and performing arts scenes. The first zine archives exhibition in Indonesia was held in this city in 2009 by Hysteria Community.

From the data above, it can be concluded that Semarang has a significant role in the activities of subculture in Indonesia, specifically zine. Zine has become an alternative media for the creators and readers as a means of spreading ideas, information as well as social and literacy movement.

\section{Literature Review}

The research or study about zine in Indonesia is relatively rare. There's a distinction among our country and other nations which have quite a long historical roots in their cultures of making zines. Research about zine in a global scale has been conducted by Paula Guerra and Pedro Quintela in a book entitled Punk, Fanzines and DIY Cultures in a Global World: Fast, Furious and Xerox. Zine cultures around the globe are discussed within the book, such as in England, Portugal, Greece, Brazil, Argentina, France, Canada, United States, and several other nations. Apart from the zine, the discussions about other subcultures are found, particularly punk music, the resistance movement and counterculture [2].

The topic about zine and its relation to counterculture has also been beautifully written by Stephen Duncombe in Notes from Underground: zones and the Politics of Alternative Culture. It is discussed within the book the significant role of zine as an alternative media to spread resistant ideas related to social and politics. Independent zines which are managed by either individual or communities speak the voice which has never been spoken in the realm of mainstream culture [1].

The research about zine conducted in Indonesia is commonly done in the realm of cultural studies, and it rarely puts zine specifically into the main topic of the research. Some academic research about zine has been conducted by Hary Ganjar Budiman entitled "The Development of Zine in Bandung: Media of Information of Underground Music Community (1995-2012)". The research focuses on the zine publication movement in Bandung which is directly related to the distribution of information, getting in touch with the existence of the underground music community. It can be inferred from this research that zine is a media that is able to represent the awareness of the identity of the community and to accommodate the emerging ideas as the answers to the social condition through the information shared [3].

Further, there is a research from Fitri Nurkumalasari entitled "Zine as a Media of Social and Political Criticism (a Study on the Terompet Rakyat Zine)". The focus of the research is on the development and the place of zine as an alternative media with Terompet Rakyat as an object through the perspective of cultural studies and semiotics [4]. The research which will be conducted is different from the previous ones. This research emphasizes the history of zine development in Semarang and its impacts on the subculture and the media of literacy in Semarang.

\section{Research Method}

The research is categorized into a field research. The research lies on the sociological basis which was done based on qualitative research. The approach used in this research is the Sociology of Literature [5], particularly the text production and distribution part. The data was obtained from the interviews with zinesters alongside their zine products. The data collection methods used were observations and deep interviews. The observation method is used to cover the data related to zine production while the deep interview method is used to 
cover the data related to the history of zine development and its impacts on the readers. The analytical method used in this research is to investigate how far zine production in Semarang is able to give impacts of literacy to both the creators and the readers through the Sociology of Literature approach (production, distribution, and reception).

\section{Zine: Between Cultural Expression and a Media of Literacy}

\subsection{Zine as a Community Media}

In the 2000s, there were a lot of zines and zine-makers who pursued this alternative pathway in Semarang. One of them was Hysteria Collective. Before reaching out to the city issues, towns, and contemporary arts, Hysteria was at first a zine of literature and literary activist group. Akhmad 'Adin' Khairudin, the director of Hysteria Collective stated that Hysteria zine emerged when zine had existed for quite a long time in Semarang. This zine first emerged in 2004 as a zine of literature by the literature students of Diponegoro University. There had been many other zines in various themes, such as fine arts, music and hardcore-punk. This zine first emerged as a place for the literature students as a means of expressing their creativity within the realm of writings [6].

When at first Hysteria zine was published, the zinesters didn't use the term zine. Adin stated that it occurred because at that time they hadn't been acquainted with the music culture which used the term zine for their alternative published products. They finally began to use the term zine in 2007 to refer to their alternative publications when they expanded their cultural focus not only onto literature, but also music, film, fine arts, and performing arts. Hysteria zine's content includes literature, from short stories and poems to cultural essays written by the contributors. Aside from that, there were also various arts and cultural event reports, held by either Hysteria or other communities.

A similar thing happened to Tanda Batja art community. This community was first established by Kelompok Belajar Apresiasi Semarang (Semarang Appreciation Study Group) in 2003. The majority of the members were performing artists. The initial idea of this community was to become an art communication media. It's interesting that even though it was an alternative publication, Tanda Batja enacted quite a strict journalism standard in each edition. They always gave rise to the main topic and issue. Further, they also included interviews with performer artists and art event coverage in Semarang. Tanda Batja lasted for two years with its last edition published in 2005 .

The popularity of zine at that time gave Hysteria confidence to hold a zine archives exhibition on 4-12 August 2009. There were 500 zines exhibited from all around Indonesia and Australia. Aside from zine, they also held other activities, such as music and literature discussions, film screening, music performance, and they also launched a zine library which is accessible until now at Grobak Art Kos Hysteria. The exhibition entitled "Jalur Alternatif" ("Alternative Pathway") wasn't labeled as a zine festival. However, almost all the content of the event was zines. One can argue that Jalur Alternatif was the first zine festival in Indonesia before the emerging of many other big zine festivals, such as Bandung Zine Fest, Indiezine Partij, Jakarta Zine Fest, Bali Zine Fest, and a lot more. Today, the festival has turned into Festival Literasi Aksara [6].

\subsection{Zine as a Media of Expression and Ideology Dissemination}

Few years before the emerging of Hysteria and Tanda Batja in Semarang, there came Kesit, a hardcore punk musician who began to create zine since 1999 . By the time, he only made simple zines sporadically. In 2001, he collaborated with Garna Raditya, his band partner in 
AK//47, a hardcore band in Semarang. They published Step from the Back, an official AK//47 zine. Previously, Garna made a zine personally entitled Pingsan (Faint).

An official zine from a band was an interesting phenomenon, for there were only few bands who were willing to do it, even in the punk scene itself. In addition to being a communication media between the musicians and the fans, the making of band zine could become the media of expression outside the music products. In each publication, they always served various kinds of writings which became the product of idealism and expression. Usually, it was related to the social problems which also became the themes of AK//47 song lyrics.

Beside Kesit and Garna, there were several names to be mentioned who were active in making zines with personal themes for instance, Gagas Agung Sedayu. He started to make zines since he was in High School. He became more attached to the zine scene while he was studying English Literature at Diponegoro University. In the 2000-2020 era, Undip's Literature campus in Pleburan became a kind of meeting place of the artists, from literature and performing arts to music (mainly punk and underground culture). In addition to doing activities related to arts through making a band, Gagas also created a zine entitled Kosong (Empty). Even though it only lasted for four editions (2008-2009), Kosong was a zine with a mature concept. The content was writings (Gagas called it personal writings in "absurd semifiction" style) with a more established literary standard compared to other zines.

In the same era emerged women zinesters. There was Marlinda Oktavia Erwanti with her two published zines: Freidanker and Xtraordinary World. Marlinda's zines focused on women issues from lifestyle, ideology, violence against women, and sexuality to reproduction health.

Another name was Annisa Rizkiana Rahmasari (Nica). Different from the previous zinesters, Nica made more visual zines. She made Gnoem-gnoem (10 volumes), Au Revoir (6 volumes), and Bundle Rumble (10-20 mini zines). The content of Nica's zines was drawings, babble, personal opinions, a little comic, short reports of independent observations about zine, favourite song lists, and interviews with her favourite drawing artists. What's more interesting was that all of them were served in colourful visual.

\subsection{Zine as a Media of Literacy}

A zine is seamlessly proven as an excellent media of literacy. From Hysteria Collective and Tanda Batja to personal zinesters have acknowledged the fact. Zines from communities have become a means of expression, discourse, and ideology which become the communities identities. That's where the interrelationship between zinesters and the readers emerged.

The discourse has become an interesting thing. Even though Kesit stated that there was never any written polemic occurred, some of his zines had successfully triggered discussions among the punk and hardcore scenesters.

On the other hand, through their activism other than zine, a lot of the zinesters have careers in the fields of literacy. The majority of the authors of Tanda Batja have finally become journalists. Today, Garna Raditya and Marlinda Oktavia Erwanti become artists as well as journalists. They stated that the zines they made have helped them in writing. Nica can also relate to the feeling. Started from zines, Nica has finally been able to become an artist, writer, and she still even creates zines until today.

Hysteria must acquire its record in the literacy in Semarang. Until this journal is written, Hysteria has been preparing its 100th edition of zine. This achievement has made Hysteria zine as a zine with the longest edition in Indonesia or even Southeast Asia. 


\section{Conclusion}

As an alternative media, zine has a significant role in the progress of culture in a certain city or town, specifically in the countercultures and sidestream cultures. Its existence has become a means of expression and personal ideology dissemination of a group that is rarely covered by mainstream cultures and media. On the other side, zine has become a means of literacy for the creators and readers. From the content of the zine, there emerges the productions of discourse and literacy. Cultural product as zine has also marked a time before the internet era penetrates all of the social aspects of the society in the future.

\section{References}

1. Stephen Duncombe. Notes from Underground: Zines and the Politics of Alternative Culture. 7 (1997)

2. Paula Guerra and Pedro Quintella (ed). Punk, Fanzines and DIY Cultures in a Global World: Fast, Furious and Xerox (2020)

3. Hary Ganjar Budiman. "Perkembangan Zine di Bandung: Media Informasi Komunitas Musik Bawahtanah (1995-2012)" in Patanjala Vol. 6, no. 1, Maret: 93-108. (2014)

4. Fitri Nurkumalasari. "Zine sebagai Media Kritik Sosial Politik (Studi pada Terompet Rakyat Zine)". UGM Repository (2018)

5. Robert Escarpit. Sosiologi Sastra. 1-2 (2005)

6. Gregorius Tri Hendrawan Manurung. "Melongok Pameran Zine Pertama di Indonesia pada 2009, Semarang Jadi Tuan Rumah". https://www.inibaru.id/indimania/melongokpameran-zine-pertama-di-indonesia-pada-2009-semarang-jadi-tuan-rumah (2020) 